\title{
The Effect of Profitability, Liquidity, and Capital Structure on Firm Value with Dividend Policy as a Moderating Variable in the Company Mining Listed on the Indonesia Stock Exchange
}

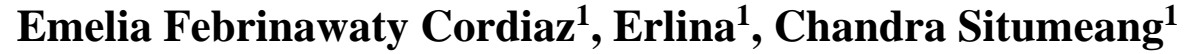 \\ ${ }^{1}$ Department of Accounting, Faculty of Economics and Business at Universitas Sumatera Utara, Indonesia \\ Corresponding Author: Emelia Febrinawaty Cordiaz
}

\begin{abstract}
The purpose of this study is to examine and analyze the effect of profitability, liquidity, and capital structure on firm value in mining companies listed on the Indonesia Stock Exchange and to test whether dividend policy can moderate the relationship between the independent variables and the dependent variable.

The population of this study is all mining companies listed on the Indonesia Stock Exchange from 2011 to 2019. The research sample was determined by the purposive sampling method, so a sample of 11 companies was multiplied by 9 years of research to obtain 99 observations. The analytical technique used in this study is moderating regression analysis (MRA) with Eviews 10 software tools.

This study partially shows that profitability has a positive effect on firm value, liquidity has a negative effect on firm value, and capital structure has a negative effect on firm value. All of these independent variables together affect firm value. The dividend policy variable moderates the relationship between profitability and firm value but does not moderate the relationship between liquidity and capital structure on firm value.
\end{abstract}

Keywords: profitability, liquidity, capital structure, dividend policy, firm value

\section{INTRODUCTION}

The purpose of establishing a company is to pursue profit by achieving a maximum profit or maximum profit and increasing shareholder prosperity through increasing company value (Harmono, 2017). Company value is the value of all assets, both operational and non-operational tangible assets. If it is related to the company's capital structure, company value can also be interpreted as the value of its overall capital structure, namely the fair market value (Prawoto, 2016). Every company generally wants a high Firm Value because a high company value indicates high shareholder prosperity. Firm value describes the company's performance that can affect the investor's point of view of the company (Arifianto and Chabachib, 2016).

Along with economic growth from time to time, the need for energy resources will automatically continue to increase. It also impacts mining companies that act as providers of energy resources in supporting economic development. In Indonesia itself, the mining industry is one of the market drivers on the Indonesia Stock Exchange. In March 2017, the mining stock sector led the increase in the Composite Stock Price Index (IHSG) in stock trading, with a gain of $0.44 \%$. In August 2019, the JCI was in the green zone, increasing the JCI by 11.48 points or $0.18 \%$. It is inseparable from the strengthening of the mining sector, which rose $0.75 \%$, especially in the coal sector, influenced by rising prices and increasing coal volumes. The coal sector is one of the strategic mining sectors in Indonesia. 
Based on data published by the BP Statistical Review of World Energy 2020 through the website www.bp.com, Indonesia occupies the second position globally with the highest increase in coal consumption after China (1.8 EJ). The increase in consumption increased the amount of coal production globally, and only Indonesia experienced a significant increase (1.3 EJ). Although since 2015 there has been a $1.3 \%$ decline in the coal trade, strong coal export growth has only been seen in Indonesia (0.6 EJ), while the United States (-0.5 EJ), Australia (-0.4 EJ), and Colombia (-0.3 EJ) experienced significant declines. However, when it comes to company value, the coal mining industry has fluctuated. It can be seen from the value of the PBV ratio, which is one of the benchmarks for company value (Harmono, 2017). The following is attached to the PBV data of coal mining companies for 2015 2018, which was obtained from the Indonesia Stock Exchange.

Table 1. PBV Value of Coal Mining Sector

\begin{tabular}{|c|c|c|c|c|c|}
\hline \multirow[b]{2}{*}{ No. } & \multirow[b]{2}{*}{ Companies } & \multicolumn{4}{|c|}{ Firm Value (PBV) } \\
\hline & & 2015 & 2016 & 2017 & 2018 \\
\hline 1 & ADRO & 0.36 & 1.08 & 1.09 & 0.63 \\
\hline 2 & ARII & 1.06 & 2.06 & 5.46 & 5.44 \\
\hline 3 & BYAN & 11.05 & 7.91 & 5.06 & 58.69 \\
\hline 4 & BSSR & 2.01 & 2.23 & 2.72 & 2.90 \\
\hline 5 & PTBA & 0.22 & 0.55 & 1.88 & 3.04 \\
\hline 6 & DOID & 0.39 & 2.57 & 2.55 & 1.33 \\
\hline 7 & DEWA & 0.23 & 0.23 & 0.23 & 0.20 \\
\hline 8 & DSSA & 0.74 & 0.35 & 0.56 & 0.46 \\
\hline 9 & GEMS & 2.41 & 4.46 & 4.09 & 3.05 \\
\hline 10 & HRUM & 0.39 & 1.21 & 1.03 & 0.67 \\
\hline 11 & INDY & 0.05 & 0.35 & 1.06 & 0.46 \\
\hline 12 & ITMG & 0.56 & 1.56 & 1.80 & 1.53 \\
\hline 13 & MBAP & 1.34 & 2.08 & 2.15 & 1.69 \\
\hline 14 & PTRO & 0.12 & 0.32 & 0.69 & 0.65 \\
\hline 15 & KKGI & 0.40 & 1.32 & 1.35 & 1.36 \\
\hline 16 & SMMT & 1.35 & 1.23 & 1.00 & 1.09 \\
\hline 17 & SMRU & 2.16 & 3.99 & 6.22 & 9.78 \\
\hline 18 & TOBA & 0.63 & 1.26 & 1.76 & 1.08 \\
\hline \multicolumn{2}{|c|}{ TOTAL } & 25.47 & 34.76 & 40.70 & 94.05 \\
\hline \multicolumn{2}{|c|}{ Average / year } & 1.42 & 1.93 & 2.26 & 5.23 \\
\hline
\end{tabular}

Based on the table above, it can be seen that the company's average PBV has increased during the 2015-2018 period. However, if observed individually, only PT. Baramulti Suksessarana Tbk, PT. Bukit Asam Tbk, PT Petrosea Tbk, PT Resources Alam Indonesia Tbk, PT SMR Utama Tbk, PT TBS Energi Utama Tbk experienced continuous increases. At the same time, the other companies were erratic (up and down. These fluctuations will affect the value of the company.

Several indicators can affect the value of the company. Among them are profitability, liquidity, capital structure projected through leverage, and dividend policy. Every company owner expects the profit generated by his company in a certain period, which can be projected through financial ratios. Profitability is one of the factors that affect the value of the company. The company's performance can be assessed by the rate of increase in company profits, which is projected through the profitability ratio (Setyawati, 2019). Profitability is the company's ability to earn profits through all existing capabilities and sources such as sales activities, cash, capital, number of employees, and number of company branches. The profitability ratio is a tool to measure the effectiveness of company management, which can be seen from the profit (profit) of sales and investment income, which also shows the company's efficiency (Fajaria and Isnalita, 2018).

Profitability can be used by the company's internal parties to set targets, budgets, coordination, evaluation of the results of the company's operations, and the basis for decision making. If the company's ability to generate profits increases, then in general, the stock price will also increase (Husnan, 2018). In other words, if the profitability of a company is getting better, then the company's value will also be better in the eyes of investors because a good level of profitability is an attraction for investors to invest in the company. In this study, profitability is proxied using Return on Equity (ROE). ROE is a ratio to measure net profit after tax with own capital.

Liquidity describes its ability to meet its short-term financial obligations, which must be met when billed to maintain liquidity (Kariyoto, 2017). The liquidity ratio measures the company's capacity to pay off its short-term debts (Lalithchandraa and Rajendhiran, 2021). Companies with a 
high level of liquidity indicate that the company's growth opportunities tend to be high (Chasanah, 2017). The more liquid the company, the higher the level of trust from creditors in providing funds to increase the company's value in the eyes of creditors and potential investors. In this study, liquidity is proxied by the Current Ratio (CR). The current ratio is used to measure a company's ability to pay off short-term obligations using all of its short-term assets.

The effect of capital structure is measured by the share capital structure of mining companies listed on the Indonesia Stock Exchange. Capital structure is a comparison between the amount of longterm debt with the company's share capital. The capital structure is the result or result of a financing decision, which in essence, will choose the use of debt or equity to fund the company's operations (Syamsuddin, 2016). Outsiders generally interpret the use of debt as the company's ability to pay obligations in the future or the company's business risk. Assessment by outsiders will certainly affect the value of the company.

Trade-Off Theory explains that if the position of the capital structure is below the optimal point, then any additional debt will increase the company's value. And vice versa. Following the Trade-Off Theory, it can be concluded that the use of debt will increase the company's value as long as it does not exceed the optimal limit. However, excessive use of debt can result in a decrease in the value of the company. In this study, the capital structure is proxied by the Debt To Equity Ratio (DER), which compares the use of debt with its capital.

Dividend policy in this study is a moderating variable, strengthening or weakening the relationship of profitability, liquidity, and capital structure to firm value. According to Hanafi (2018), dividends are compensation received by shareholders. In addition to capital gains, dividends are the proportion of profits distributed to shareholders in an amount proportional to the number of shares they own. Investors generally want a relatively stable dividend distribution because dividend stability can increase investor confidence in the company (Septian and Lestari, 2016). While dividend policy is related to the company's financial policy regarding how much profit will be distributed to shareholders or as retained earnings (Wiagustini, 2010 in Putri and Wiksuana, 2021). Improved financial performance can increase firm value (Widagdo et al., 2020). Good financial performance will generate increased profits and have an impact on increasing dividends distributed. The dividend is a form of feedback (return) to investors to maximize the company's value in the eyes of investors (Jooman et al., 2020).

Profits and policies regarding dividend distribution are matters related to company decisions. When the company earns profits and implements a dividend distribution policy to shareholders, this is a positive signal for shareholders or potential investors. It was due to investors' expectations of getting a return in the form of cash dividends that can be realized so that the company will be seen as having good growth and increasing value from the company itself. In this study, dividend policy is proxied as the Dividend Payout Ratio (DPR), which measures the proportion of dividends distributed to shareholders.

\section{PREVIOUS RESEARCH REVIEW}

According to research by Nurhayati and Nurhayati \& Kartika (2020), profitability has a positive effect on firm value, while capital structure does not significantly affect firm value. It is in line with the results of research by Suwardika and Mustanda (2017). In Alamsyah and Muchlas's (2018) research, which states that capital structure has a direct and positive effect on firm value, dividend policy mediates the effect of ownership structure on firm value. According to Ardina and Isnalita (2018), in their research, they conclude that profitability has a significant effect on firm value with dividend policy as moderating, while liquidity and leverage have a significant negative effect on firm 
value. Rehman (2016), in his research, concludes that capital structure has a significant effect on firm value. In Triasesiarta's research (2018), profitability has no significant effect on firm value. According to Zuhroh (2019), in his research, profitability directly has a positive effect on firm value, with leverage as a moderating variable. The results of the same study were also stated by Repi et al. (2016), Rochmah and Fitria (2017), Shalini (2020), and Puspitaningtyas (2017), Tahu and Susilo (2017), dividend policy does not moderate the effect of profitability on firm value. Profitability directly has a positive effect on firm value. Prommin (2016) found that liquidity has a significant positive effect on firm value. These results align with the research results by Sukarya and Baskara (2019) and Jinmin Du et al. (2016). Different results were presented by research by Ardina and Isnalita (2018), where liquidity and leverage have a negative effect on firm value. This result is in line with Zuhroh (2019) and Batten and Vo (2017).

According to Hirdinis' research (2019), capital structure has a positive and significant effect on firm value. The same study results were also stated by Alamsyah and Muchlas (2018), Rehman (2016). It is different from the results of Triasesiarta (2018) and Wiwit's (2019) research, which reveal that capital structure has a negative and insignificant effect on firm value.

According to Mery's research (2017), dividend policy can moderate the relationship between liquidity and firm value. In the research of Nurhayati and Kartika (2020) and Oktaviani and Mulya (2018), they conclude that dividend policy can strengthen the effect of capital structure on firm value. Meanwhile, according to the research results conducted by Prasetya and Musdholifah (2020), dividend policy cannot moderate the relationship between the DER ratio and firm value. It is in line with the research results of Tahu and Susilo (2017) and Sisca (2016),

Based on the phenomenon of fluctuations in PBV and profitability and inconsistent research results, the researchers are interested in researching with the title "Analysis of Factors Affecting Firm Value With Intellectual Capital as Moderating in Compass 100 Stock Companies Listed on the Indonesia Stock Exchange".

\section{Framework}

Following the description of the background of the problem, literature review, and previous research, a conceptual research framework is prepared as follows:

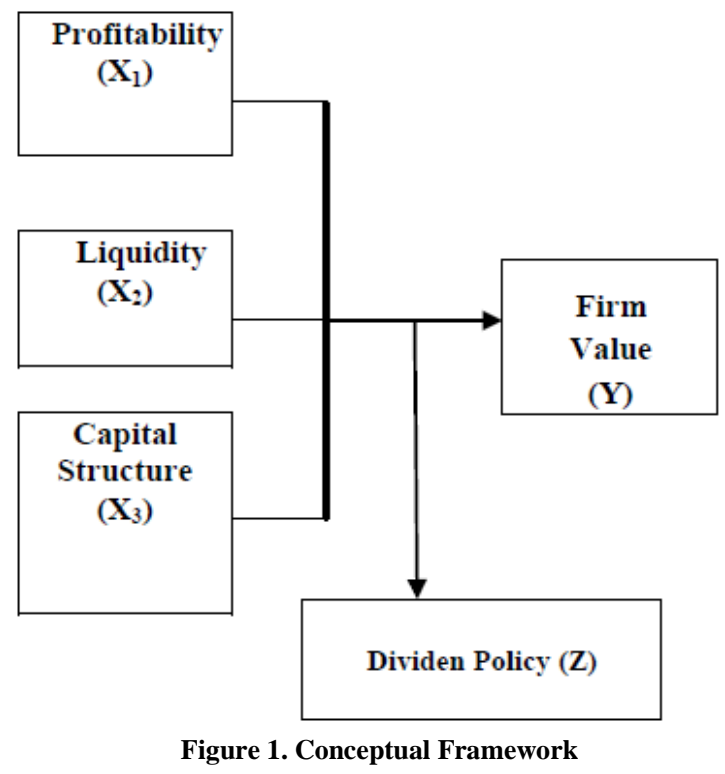

H1: Profitability has a positive effect on firm value.

H2: Liquidity has a positive effect on firm value.

H3: Capital structure has a positive effect on firm value.

H4: Profitability, liquidity, and capital structure affect the firm value simultaneously.

H5: Dividend policy can moderate the effect of profitability on firm value.

H6: Dividend policy can moderate the effect of liquidity on firm value.

H7: Dividend policy can moderate the effect of capital structure on firm value.

\section{RESEARCH METHODS}

This type of research is causal associative research to determine the effect of Profitability, Liquidity, and Capital Structure as independent variables on 
Emelia Febrinawaty Cordiaz et.al. The effect of profitability, liquidity, and capital structure on firm value with dividend policy as a moderating variable in the company mining listed on the Indonesia stock exchange.

Company Value as the dependent variable with Dividend Policy as the moderating variable. The causal associative study analyzes the relationship between one variable and another to determine how one affects other variables (Erlina, 2011). The data analysis method used in this study is a statistical analysis method using the Eviews10 application. Data analysis performs by testing standard assumptions and testing hypotheses.

The population used in this study were 47 mining companies listed on the Indonesia Stock Exchange in 2011-2019. This research uses the purposive sampling technique. The samples of this research are 11 companies obtained multiplied by 9 years of research to obtain 99 observations.

\section{RESULT AND DISCUSSION Normality Test}

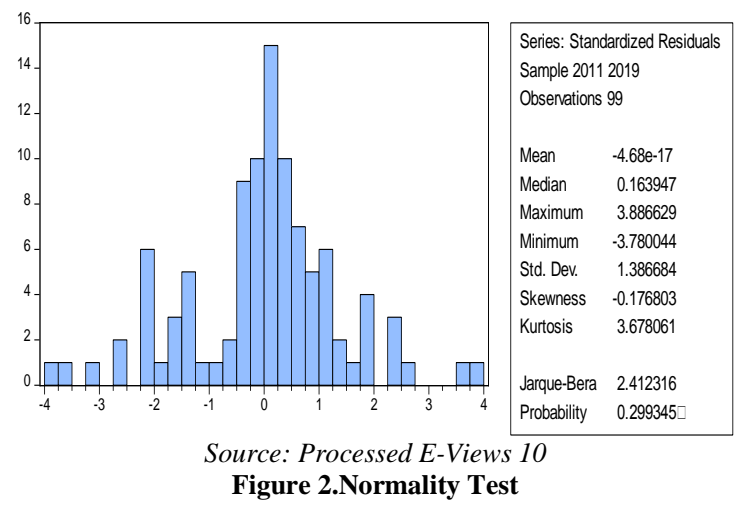

Based on the picture above, it can be concluded that the probability value of 0.202420 is greater than 0.05 , which indicates that the data is normally distributed. So that further testing can be carried out.

\section{Panel Data Regression Model Estimation}

To analyze panel data, the thing that must be done is to analyze the Common Effect Model (CEM), Fixed Effect Model (FEM), and Random Effect Model (REM) to determine the appropriate model to use. Common Effect Model Test
Table 2.Common Effect Model Estimation Results

\begin{tabular}{lrrrr}
\hline Variable & Coefficient & Std. Error & t-Statistic & Prob. \\
\hline C & 2.820254 & 0.388892 & 7.252034 & 0.0000 \\
X1 & 0.050336 & 0.042177 & 1.193453 & 0.2357 \\
X2 & -0.122241 & 0.113515 & -1.138535 & 0.2578 \\
X3 & -0.811160 & 0.192409 & -4.215817 & 0.0001 \\
& \multicolumn{4}{c}{ Source: Processed E-Views 10 }
\end{tabular}

From the results of the regression common effect models, it can be concluded that profitability positively affects firm value. In contrast, liquidity and capital structure have a partial negative effect on firm value.

Fixed Effect Model Test

\begin{tabular}{|c|c|c|c|c|c|}
\hline & Variable & Coefficient & Std. Error & t-Statistic & Prob. \\
\hline C & & 2.699833 & 0.331685 & 8.139758 & 0.0000 \\
\hline X1 & & 0.054325 & 0.029817 & 1.821910 & 0.0720 \\
\hline$X 2$ & & -0.065489 & 0.113377 & -0.577622 & 0.5650 \\
\hline X3 & & -0.829909 & 0.189409 & -4.381580 & 0.0000 \\
\hline
\end{tabular}

From the regression results of fixedeffect models, it can be concluded that profitability positively affects firm value. In contrast, liquidity and capital structure have a partial negative effect on firm value.

\section{Random Effect Model Test}

\begin{tabular}{|c|c|c|c|c|}
\hline Variable & Coefficient & Std. Error & t-Statistic & Prob. \\
\hline C & 2.714669 & 0.482870 & 5.621947 & 0.0000 \\
\hline X1 & 0.053949 & 0.029805 & 1.810030 & 0.0735 \\
\hline$X 2$ & -0.075626 & 0.108650 & -0.696050 & 0.4881 \\
\hline X3 & -0.822544 & 0.181919 & -4.521475 & 0.0000 \\
\hline
\end{tabular}

Source: Processed E-Views 10 
Emelia Febrinawaty Cordiaz et.al. The effect of profitability, liquidity, and capital structure on firm value with dividend policy as a moderating variable in the company mining listed on the Indonesia stock exchange.

From the estimation results of random effect models, it can be concluded that profitability positively affects firm value. In contrast, liquidity and capital structure have a partial negative effect on firm value.

\section{Panel Data Regression Model Selection}

There are three tests to decide which model to use: the Chow Test, Hausman Test, and Langrange Multiplier Test.

\section{Chow Test}

\begin{tabular}{|c|c|c|c|}
\hline Effects Test & Statistic & d.f. & Prob. \\
\hline Cross-section F & 10.624978 & $(10,85)$ & 0.0000 \\
\hline Cross-section Chi-square & 80.281975 & 10 & 0.0000 \\
\hline
\end{tabular}

Source: Processed E-Views 10

The table above shows that the probability value of 0.0000 is smaller than 0.05, so the Fix Effect Model (FEM) is better than the Common Effect Model (CEM).

\section{Hausman Test}

\begin{tabular}{lrrr}
\multicolumn{4}{c}{ Table 6. Hausman Test Estimation Results } \\
\hline \hline Test Summary & Chi-Sq. Statistic & Chi-Sq. d.f. & Prob. \\
\hline \hline & & & \\
Cross-section random & 0.753150 & 3 & 0.8606 \\
\hline \hline
\end{tabular}

Source: Processed E-Views 10

The table above shows that the probability value $=0.8606$ is greater than 0.05 , so the model that is feasible to use is the Fixed Effect Model (FEM).

\section{Hypothesis test}

Hypothesis testing in this study using the estimation results of the Random Effect Model (REM) regression model.

\section{Coefficient of Determination Test}

Table 7. Coefficient of Determination Test Results

\begin{tabular}{llll}
\hline \hline & Weighted Statistics & \\
\hline \hline R-squared & 0.193609 & Mean dependent var & 0.475425 \\
Adjusted R-squared & 0.168144 & S.D. dependent var & 1.073686 \\
S.E. of regression & 0.979268 & Sum squared resid & 91.10167 \\
F-statistic & 7.602968 & Durbin-Watson stat & 1.269703 \\
Prob(F-statistic) & 0.000131 & \\
\hline \hline
\end{tabular}

Source: Processed E-Views 10

Based on the table above, it can be seen that the Adjusted R-Squared value is 0.168144 . It means that the magnitude of the role or contribution of the independent variables, namely profitability (ROE), liquidity (CR), and capital structure (DER) which can explain the dependent variable, namely firm value (PER) simultaneously or together is $16.81 \%$. In contrast, the remaining $83.19 \%$ is explained by other variables.

\section{Partial Test (t-Test)}

\begin{tabular}{|c|c|c|c|c|c|}
\hline & Variable & Coefficient & Std. Error & t-Statistic & Prob. \\
\hline C & & 2.714669 & 0.482870 & 5.621947 & 0.0000 \\
\hline X1 & & 0.053949 & 0.029805 & 1.810030 & 0.0735 \\
\hline X2 & & -0.075626 & 0.108650 & -0.696050 & 0.4881 \\
\hline X3 & & -0.822544 & 0.181919 & -4.521475 & 0.0000 \\
\hline
\end{tabular}

Source: Processed E-Views 10

Based on the table above, it can be concluded that profitability has a positive effect on the firm value variable. In contrast, liquidity and capital structure have a negative effect on firm value partially.

\section{Simultaneous Test (F Test)}

The table shows the value of Prob. (F-statistics) of $0.000131 \quad(<0.05)$. Therefore, it can be concluded that all independent variables (free), namely profitability, liquidity, and capital structure, 
simultaneously have a significant effect on firm value as the dependent variable (bound).

Table 9. Simultaneous Test Result

\begin{tabular}{llll}
\hline \multicolumn{4}{c}{ Table 9. Simultaneous Test Result } \\
& Weighted Statistics & \\
\hline \hline & & & \\
R-squared & 0.193609 & Mean dependent var & 0.475425 \\
Adjusted R-squared & 0.168144 & S.D. dependent var & 1.073686 \\
S.E. of regression & 0.979268 & Sum squared resid & 91.10167 \\
F-statistic & 7.602968 & Durbin-Watson stat & 1.269703 \\
Prob(F-statistic) & 0.000131 & \\
\hline \hline
\end{tabular}

Source: Processed E-Views 10

\section{Moderating Regression Analysis (MRA)} Test

Table 10. Moderating Regression Analysis (MRA) Test Result

\begin{tabular}{|c|c|c|c|c|c|}
\hline & Variable & Coefficient & Std. Error & t-Statistic & Prob. \\
\hline C & & 2.856754 & 0.519732 & 5.496592 & 0.0000 \\
\hline $\mathrm{X} 1$ & & 0.226409 & 0.064988 & 3.483868 & 0.0008 \\
\hline$X 2$ & & -0.082135 & 0.110078 & -0.746156 & 0.4575 \\
\hline X3 & & -0.818555 & 0.181654 & -4.506125 & 0.0000 \\
\hline $\mathrm{X} 1 * \mathrm{Z}$ & & -0.540185 & 0.186464 & -2.896990 & 0.0047 \\
\hline $\mathrm{X} 2 * \mathrm{Z}$ & & -0.016063 & 0.132318 & -0.121395 & 0.9036 \\
\hline $\mathrm{X} 3 * \mathrm{Z}$ & & -0.177428 & 0.449972 & -0.394309 & 0.6943 \\
\hline
\end{tabular}

From the results of the MRA test above, it can be seen that dividend policy moderates profitability on firm value. Dividend policy is not able to moderate liquidity to firm value. Dividend policy is not able to moderate the capital structure variable on firm value.

\section{CONCLUSION}

Based on the results of data analysis and research discussion, the following conclusions can be drawn:

1. Profitability as proxied through the Return On Equity (ROE) ratio partially has a positive and insignificant effect on firm value proxied by Price Earning Ratio (PER).

2. As proxied by the Current Ratio (CR) partially, Liquidity has a negative and insignificant effect on firm value as proxied by Price Earning Ratio (PER).
3. The capital structure, which is proxied through Debt to Equity Ratio (DER), partially has a negative and significant effect on firm value which is proxied by Price Earning Ratio (PER).

4. Dividend policy proxied using the Dividend Payout Ratio (DPR) can moderate profitability as proxied by Return On Equity (ROE) to firm value proxied through Price Earning Ratio (PER).

5. All independent variables (free), namely profitability (ROE), liquidity (CR), and capital structure (DER), simultaneously have a significant effect on firm value (PER) as the dependent variable (bound).

6. The dividend policy proxied using the Dividend Payout Ratio (DPR) is not able to moderate liquidity as proxied by the Current ratio (CR) to the firm value proxied through the Price Earning Ratio (PER).

7. Dividend policy proxied using the Dividend Payout Ratio (DPR) is not able to moderate the capital structure proxied by the Debt to Equity Ratio (DER) to firm value proxied through the Price Earning Ratio (PER).

\section{Limitations Of The Research}

1. The independent variable used only consists of 3 variables, so there may still be other variables that can affect the company's value.

2. The sample in this study only uses mining companies listed on the Indonesia Stock Exchange.

3. This study uses a data range from 2011 to 2019 , so it is possible to obtain different research results from different data ranges.

\section{Suggestion}

1. The next researchers are expected to test other variables to see their effect and different results on firm value.

2. This research is limited to mining companies listed on the Indonesia Stock Exchange so that future researcher are 
Emelia Febrinawaty Cordiaz et.al. The effect of profitability, liquidity, and capital structure on firm value with dividend policy as a moderating variable in the company mining listed on the Indonesia stock exchange.

expected to be able to research different company sectors.

3. Future researchers are expected to use different data ranges to obtain different research results to add insight and information to the readers.

\section{Acknowledgement: None}

\section{Conflict of Interest: None}

\section{Source of Funding: None}

\section{REFERENCES}

1. Alamsyah, A., R., \& Muchlas, Z. (2018). Pengaruh Struktur Kepemilikan, Struktur Modal, dan IOS Terhadap Nilai Perusahaan dengan Kebijakan Dividen sebagai Variabel Intervening pada Perusahaan Manufaktur Terdaftar di BEI. Jurnal Ilmiah Bisnis Dan Ekonomi Asia Vol. 12, No. 1. DOI: https://doi.org/10.32812/jibeka.v12i1.5

2. Arifianto, Mukhammad dan Chabachib, Mochammad. (2016). Analisis Faktor Faktor yang Mempengaruhi Nilai Perusahaan (Studi Kasus Pada Perusahaan Yang Terdaftar Pada Indeks LQ-45 Periode 2011-2014). Diponegoro Journal Of Management Volume 5 , No. 1, ISSN (Online): 2337-3792. Http://ejournals1.undip.ac.id/index.php/dbr

3. Batten, Jonathan J., \&, Vo, X., V. (2017). Liquidity and Firm Value in an Emerging Market. The Singapore Economic Review, 64 https://doi.org/10.1142/S021759081747006 3

4. Chasanah, Amalia Nur. (2018). Pengaruh Rasio Likuiditas, Profitabilitas, Struktur Modal, dan Ukuran Perusahaan Terhadap Nilai Perusahaan pada Perusahaan Manufaktur yang Terdaftar di BEI tahun 2015-2017. Jurnal Penelitian Ekonomi dan Bisnis, 3 (1), 39 - 47.

5. Erlina. 2011. Metodologi Penelitian Bisnis untuk Akuntansi dan Manajemen. USU Press, Medan.

6. Fajaria, Ardina Zahrah \& Isnalita. (2018). The Effect of Profitability, Liquidity, Leverage and Firm Growth of Firm Value with its Dividend Policy as a Moderating Variable. International Journal of Managerial Studies and Research (IJMSR)
Volume 6, Issue 10, October 2018, PP 55-69, ISSN 2349-0330. http://dx.doi.org/10.20431/23490349.0610005

7. Hanafi, Mamduh $\mathrm{M}$ dan Abdul Halim. (2018). Analisis Laporan Keuangan Edisi Kelima, Cetakan Kedua. Yogyakarta, Indonesia: UPP STIM YKPN.

8. Harmono. (2017). Manajemen Keuangan Berbasis Balanced Scorecard Pendekatan Teori, Kasus, dan Riset Bisnis. Jakarta, Indonesia: Bumi Aksara.

9. Hirdinis, M. (2019). Capital Structure and Firm Size on Firm Value Moderated by Profitability. International Journal of Economics and Business Administration, Volume VII, Issue 1, pp. 174-191. DOI: 10.35808/ijeba/204

10. Jooman, Kim dkk. (2020). The Impact of R\&D Intensity, Financial Constraints, and Dividend Payout Policy on Firm Value. Finance Research Letters Volume 40, Elsevier. https://doi.org/10.1016/j.frl.2020.101802

11. Kariyoto. (2017). Analisa Laporan Keuangan, Cetakan Pertama. Malang, Indonesia: UB Press (UB Media).

12. Lalithchandraa, B., N., \& Rajendhiran, N. (2021). Liquidity Ratio: An Important Financial Metrics. Turkish Journal of Computer and Mathematics Education Vol. 12 No. 2, 1113 - 1114. DOI: https://doi.org/10.17762/turcomat.v12i2.112 9

13. Mery, Noviem. (2017). The Effect of Liquidity, Leverage and Profitability of the Corporate's Value with Dividend Policy as Moderation on Mining Companies at The Indonesia Stock Exchange Year 2011-2014. JurnalOnline Mahasiswa Fakultas Ekonomi Universitas Riau (JOM Fekon Vol. 4No.1). https://www.neliti.com

14. Nurhayati, I., \& Kartika, A. (2020). Pengaruh Struktur Modal dan Profitabilitas Terhadap Nilai Perusahaan dengan Kebijakan Dividen Sebagai Variabel Moderasi Pada Perusahaan Manufaktur Tahun 2016-2018. Dinamika Akuntansi, Keuangan dan Perbankan, , Vol. 9, No. 2, ISSN: 2656-4955 (media online): 26568500 (media cetak).

15. Oktaviani, R., F., \& Mulya, A. (2018). Pengaruh Struktur Modal dan Profitabilitas terhadap Nilai Perusahaan dengan Kebijakan Dividen sebagai Moderasi. 
Emelia Febrinawaty Cordiaz et.al. The effect of profitability, liquidity, and capital structure on firm value with dividend policy as a moderating variable in the company mining listed on the Indonesia stock exchange.

Jurnal Akuntansi dan Keuangan FEB Universitas Budi Luhur, Vol. 7 No.2, ISSN: 22527141

16. Prasetya, A., W., \& Musdholifah. (2020). Pengaruh Likuiditas, Profitabilitas, dan Leverage Terhadap Nilai Perusahaan Yang Di Moderasi oleh Kebijakan Dividen. Jurnal Ilmu Manajemen Volume 8 Nomor 4. DOI:

http://dx.doi.org/10.26740/jim.v8n4.p14061416

17. Prawoto, Agus. (2016). Penilaian Usaha Edisi Kedua. Yogyakarta, Indoneisa: BPFE Yogyakarta, ISBN 978979503608

18. Prommin, P., Jumreornvong, S., Jirapornc, P., \& Tong, S. (2016). Liquidity, ownership concentration, corporate governance, and firm value: Evidence from Thailand. Global Finance Journal, GLOFIN-00354; No of Pages 15. www.elsevier.com/locate/gfj. http://dx.doi.org/10.1016/j.gfj.2016.06.006

19. Puspitaningtyas, Zarah. (2017). Efek Moderasi Kebijakan Dividen dalam Pengaruh Profitabilitas Terhadap Nilai Perusahaan Manufaktur. Jurnal Akuntansi, Ekonomi dan Manajemen Bisnis Article History Vol. 5, No. 2, 173-180. E-ISSN: 2548-9836.

https://doi.org/10.30871/jaemb.v5i2.538

20. Putrid, Made Olivia Dwi dan Wiksuana. (2021). The Effect Of Liquidity and Profitability on Firm Value Mediated by Dividend Policy. American Journal of Humanities and Social Sciences Research (AJHSSR), e-ISSN: 2378-703X, Volume-5, Issue-1, pp-204-212. www.ajhssr.com

21. Rehman, Obaid. (2016). Impact of Capital Structure and Dividend Policy on Firm Value. Journal of Poverty, Investment and Development, Vol.21, ISSN 2422846X. https://www.iiste.org

22. Repi, S., Murni, S., \& Adare, D. (2016). Faktor-Faktor yang Mempengaruhi Nilai Perusahaan Subsektor Perbankan pada BEI dalam Menghadapi MEA. JURNAL EMBA: JURNAL RISET EKONOMI, MANAJEMEN, BISNIS DAN AKUNTANSI, Vol.4 No.1, Hal. 181191,ISSN: 2303-1174. DOI: https://doi.org/10.35794/emba.v4i1.11585

23. Rochmah, Ainur, S., \& Fitria, A. (2017). Pengaruh Kinerja Keuangan Terhadap Nilai Perusahaan: Kebijakan Dividen sebagai Variabel Moderating. Jurnal Ilmu dan Riset Akuntansi Volume 6, Nomor 3. ISSN: 2460-0585.

24. Septian, Riantino dan Henny Setyo Lestari. (2016). Faktor Yang Mempengaruhi Dividend Policy Pada Perusahaan NonFinancial Yang Terdaftar di Bursa Efek Indonesia. Seminar Nasional Cendekiawan 2016 ISSN (E) : 2540- 7589, ISSN (P) : 2460-8696.

25. Setyawati, Wiwit. (2019). Pengaruh Struktur Kepemilikan, Struktur Modal, Profitabilitas Terhadap Nilai Perusahaan dengan Kebijakan Dividen sebagai Moderasi (Studi Empiris pada Perusahaan Sektor Pertambangan yang Terdaftar di BEI Periode 2011 - 2015). Jurnal Akuntansi Berkelanjutan Indonesia Vol.2, No. 2.

26. Shalini, Witya. (2020). Pengaruh Struktur Kepemilikan dan Kinerja Keuangan Terhadap Nilai Perusahaan dengan Kebijakan Dividen Sebagai Variabel Moderating pada Perusahaan Properti dan Real Estate yang Terdaftar di BEI Periode 2010-2018. Tesis. Universitas Sumatera Utara.

27. Sisca. (2016). Pengaruh Leverage dan Profitabilitas Terhadap Nilai Perusahaan dengan Kebijakan Dividen sebagai Variabel Moderating pada Perusahaan Manufaktur yang Terdaftar di Bursa Efek Indonesia tahun 2010 - 2014. Jurnal Manajemen dan Keuangan SULTANIST, Vol. 4, No. 1, ISSN: 2338-4328

28. Sukarya, I., P., \& Baskara, I., G. (2019). Pengaruh Profitabilitas, Leverage, dan Likuiditas Terhadap Nilai Perusahaan Sub Sektor Food And Beverages. E- Jurnal Manajemen, Vol. 8, No. 1, 2019: 7399 7428, ISSN: 23028912.DOI:https://doi.org/10.24843/EJMUN UD.2019.v8.i1.p16

29. Suwardika, A., \& Mustanda, K. (2017). Pengaruh Leverage, Ukuran Perushaan, Pertumbuhan Perusahaan, dan Profitabilitas Terhadap Nilai PerusahaanPada Perusahaan Properti. E-Jurnal Manajemen Unud, Vol. 6, No. 3: 1248-1277, E-ISSN: 2302-8912. https://ojs.unud.ac.id

30. Syamsuddin, L. (2016). Manajemen Keuangan Perusahaan, Edisi baru, ISBN: 979-421-186-9. Jakarta, Indonesia: PT Raja Grafindo Persada.

31. Tahu, G., \& Susilo, D. (2017). Effect of Liquidity, Leverage, and profitability on The Firm Value (Dividend Policy as 
Emelia Febrinawaty Cordiaz et.al. The effect of profitability, liquidity, and capital structure on firm value with dividend policy as a moderating variable in the company mining listed on the Indonesia stock exchange.

Moderating Variable) in Manufacturing Company of Indonesia Stock Exchange. Research Journal of Finance and Accounting Vol.8, No.18,

32. Triasesiarta, Nur. (2018). Pengaruh growth opportunity, profitabilitas dan struktur modal terhadap nilai perusahaan dengan dividen sebagai variabel intervening pada perusahaan manufaktur yang terdaftar di BEI pada periode 2014-2017. Jurnal Manajemen Bisnis Indonesia Vol. 5, No. 3. https://www.researchgate.net/publication.

DOI: $10.31843 / j m b i . v 5 i 3.175$

33. Widagdo, B., M. Jihadi, Y. B., Oky, E. S., \& Sanju, K. S. (2020). Financial Ratio, Macroeconomy, and Investment risk on Sharia Stock Return. Journal of Asian Finance, Economics, and Business, 7(12), 919-926, volume 7 no. 12.919. https://doi.org/10.13106/jafeb.2020.
34. Zuhroh, Ida. (2019). The Effects of Liquidity, Firm Size, and Profitability on the Firm Value with Mediating Leverage. The 2nd International Conference on Islamic Economics, Business, and Philanthropy (ICIEBP) Theme: Sustainability and Socio-Economic Growth, KnE Social Sciences, pages 203-230. DOI: 10.18502/kss.v3i13.4206

How to cite this article: Emelia Febrinawaty Cordiaz, Erlina, Chandra Situmeang. The effect of profitability, liquidity, and capital structure on firm value with dividend policy as a moderating variable in the company mining listed on the Indonesia stock exchange. International Journal of Research and Review. 2021; 8(12): 328-337. DOI: https://doi.org/10. 52403/ijrr.20211241 